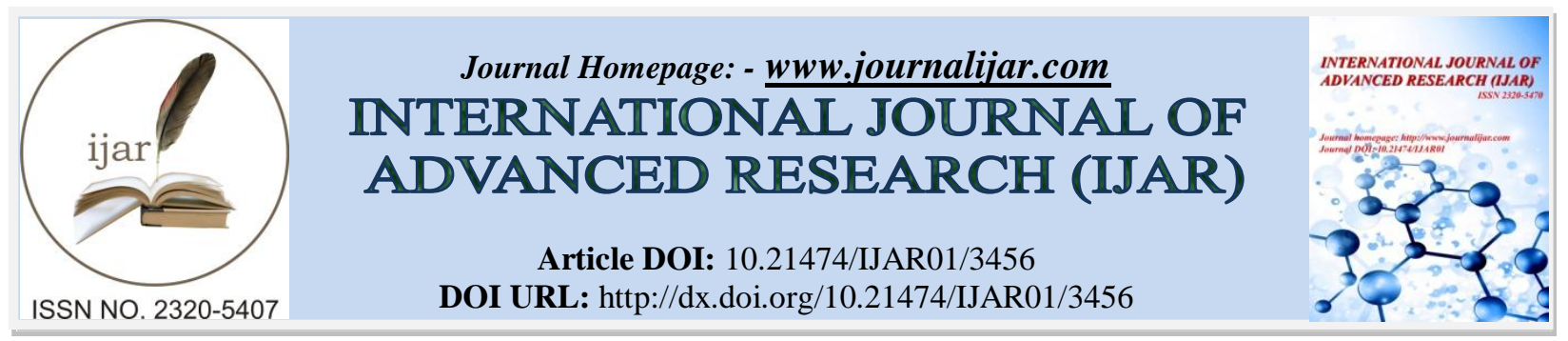

RESEARCH ARTICLE

\title{
CULTURAL CONFLICTS IN ALICE WALKER'S THE THIRD LIFE OF GRANGE COPELAND.
}

Ghansham S Baviskar ${ }^{1}$ and Dr. S. P. Zanke ${ }^{2}$.

1. PhD Research Scholar, Dept of English, Bhusawal Arts, Science \& P.O.Nahata Commerce College, Bhusawal.

2. Research Supervisor, \& Head, Dept of English, Bhusawal Arts, Science \& P.O.Nahata Commerce College, Bhusawal.

\section{Manuscript Info}

\section{Manuscript History}

Received: 15 December 2016

Final Accepted: 17 January 2017

Published: February 2017

Key words:-

repression, inequality, sharecropping, authority, emergent

\begin{abstract}
Racial inequalities imposed on African American Americans resulted in historic repression of the blacks and created an imbalance in society to give a way to conflict for human rights in racially fraught America. It offered authority to whites and relegating the blacks to the rags. The whites dominated each sphere in economy and there was no scope left for the blacks. Racial crisis and cultural conflicts drove the blacks in utter poverty and rejected the right to life. Alice Walker as an eminent African American writer deals with the ethnic issues and throws light on the historic repression of the blacks in America to voice the African Americans. Her firsthand experience of her parents' lives as sharecroppers and their brutal exploitation enabled her to view it in her works more realistically. It encouraged the humanists to fight for the human rights in racially fraught America. The abolition of slavery did not uproot sharecropping completely. It continued even in more crude and violent form, ruined the blacks, and rejected them life worth to live as free human beings.
\end{abstract}

Copy Right, IJAR, 2017,. All rights reserved.

\section{Introduction:-}

The roots of cultural conflict in American society are in the white class mentality. The whites strongly believed in the subjugation and oppression of the African Americans and denied them their human rights. The proclamation of the abolition of slavery did not end the exploitation and discrimination in American society. The exploitation continued even in the most brutal crude forms of sharecropping system that oppressed blacks and propelled them to live in utter poverty, and rejected them their right to life. The cultural imperialism of the white masters denied the blacks their recognition as human beings, relegated them to the rags, and labelled them as bonded labourers. In Society and Self in Alice Walker's In Love and Trouble, Dolan Hubbard strikingly points out this reality: "Despite the abolition of slavery, blacks find it extremely difficult to redefine their historic roles as labourers in a culture that is antagonistic to their very being" (Hubbard 2000, 212)

Alice Walker throws light on the devastating effects of cultural conflicts on the blacks that propelled them to be bonded labourers in sharecropping system, which ruined their lives. In this regard Barbara Christian's observation about the cultural crisis between the blacks and whites that arise due to the bonded labour is striking. She says, "By tracing the history of Copeland family through three generations, Walker demonstrates the relationship between the racist sharecropping system and the violence that the men, women, and children of that family inflict on each other."(Christian 1985, 84) The cultural conflict between the whites and blacks had strong negative impact on the 
families of the black people. Whites' cultural domination over the blacks destroyed the harmony in familial relationships in America and resulted into a family crisis. Grange Copeland, the protagonist throws more light on it. His exploitation as a sharecropper at the hands of his white master makes him more violent and abusive and turns him into a habitual drunkard who starts using his power against the weaker ones in his own family to get some power of feeling and authority over the family members. Alcohol serves here a means of an agent to take out his anger not on the white master but his wife and son. N. Seraman, N and A.R.Thillaikkarsi precisely comment on it and substantiate the same. They state, "He threatens his wife and son, taking too much of alcohol. It is a way to get some feeling of power."(Seraman 2013, 22)

His trap in cultural flux penetrates conflict in his own mind that does not allow him to understand the significance of education and as a result, he deprives Brownfield education. Grange's denial of education to his son proves how the slavery continued in sharecropping, kept the African Americans ignorant about the change that would come with education and relegated them to live their lives in abject poverty all their lives. Grange's exploitation in systemized bonded labour results in frustration that he inflicts on his wife and son. This cultural and racial crisis thus results in complete deterioration of Grange and his family. The exploitative nature of sharecropping that has its roots in cultural dominance, authority spoils Grange's life, and he remains in debt that he will never be able to pay off to his white master. His wife, Margaret tries to save her husband from the debt but in her attempts, she becomes a prey to the lust of the landlord. Thus, sharecropping does not result in mere Grange's exploitation in tiresome hard work but also a rape that Margaret is a victim of in a racist society that strongly imbibes the idea that the whites do have right to the black women. In this regard, Bell Hooks rightly comments on the black women's exploitation by the whites and the black masters, "American women have been socialized, even brainwashed to accept a version of American history that was created to uphold and maintain racial imperialism in the form of white supremacy and sexual imperialism in the form of patriarchy." (Hooks 1990, 120)

Cultural crisis and repression of the blacks ruined the entire humanity and brought the two cultures in flux. As the whites were in authority, their families did not suffer, rather they enjoyed the feeling of superiority over the black ones and did not question the unequal laws that stamped their authority. Even the black solidarity formed of the black community was not strong to stop wrong things happening in black culture. As a result the black women and children suffered and the black men became irresponsible and unaccountable towards their duties. In Grange's case, his failure in his duties as a husband and a father results in Margaret's suicide. Brownfield who is left orphaned too becomes what his father has left him for. He becomes the most degraded character in Walker's fiction.

Grange Copeland heads north to find some meaning in his life. But the intention with which he moves there results in despair and he soon finds the world unkind brutally ruled by the white cultural dominance everywhere. His encounter with a white pregnant woman who is deserted by her lover at the lake arises in him sentiments and the feelings of humanity for her. In order to save her from drowning in a frozen lake, he offers his hand to the woman who in turn calls him a nigger and humiliates him. Her expression of vicious hatred and racism directed at him angers him and he drops the idea of saving her and leaves the park. His encounter with the white pregnant woman results in cultural conflicts that leaves him repelled and he does not find any feelings of sympathy for anyone thereafter. In his violent disposition, that is the result of cultural domination and whites' superiority and authority over the blacks turns into violent anger that he vents at the whites and picks quarrels with them and fights with them. After realizing the futility of his actions, he soon returns south and tries to make amend for the wrongs, he caused in Brownfield's life, but finds that his son, Brownfield, rejects him. Grange takes the custody of Ruth after his son brutally kills his wife. Grange loves Ruth, sings and dances with her, tells her stories and even shares with her his experiences that he had in a culturally white dominated world. He shares, "The white folks hated me and I hated myself until I started hating them in return and loving myself. Then I tried just loving me, and then you, and ignoring them much as I could" (Walker 2004, 252) What Grange shared with Ruth throws light on Grange's response to the whites' hatred for him and the self realization that he should not hate himself but love. His vast experiences both in the south and north make him realize his sense of duty that he must have towards himself. He offers education to Ruth that he had denied to Brownfield. And for that purpose, he steals the books from the whites to provide her access in every subject to broaden her vision and understanding of the world around. Grange's sense of responsibility to look after his grandchild Ruth and protect her from every hostile culture and the deadly trap sets him on a new path for his emancipation into the first emergent black male protagonist in Alice Walker's entire work of fiction. He outshines as a wonderful human being completely changed and enamoured by the real feelings of love compassion, pity and sympathy that he completely missed in his earlier life. 
Grange Copeland, in his pursuit of truth and his struggle with culturally dominated forces and the unjust law machinery and the court verdict, shoots his son in the court and makes his way to his farm with Ruth not to find an escape but to protect Ruth from the evil unjust court and law machinery that prevailed at the time. In his pursuit to save Ruth, he dies in the firing with the police. Grange's fight with the court throws light on the white culture that advocates unjust laws and discriminates between the blacks and the whites by affirming its trust in favouritism.

Cultural conflict does not end with Grange's fight with it but it continues even in the most evil form in Brownfield's life. Like Grange, Brownfield too becomes a victim of dehumanized culture that strongly believes in blacks' subjugation and oppression. Edwin Mhandu's observation in this regard is striking. He says, "Brownfield, as his name signifies, is a victim of the sharecropping system with its brown fields that is controlled by white as typified by Shipley." (Mhandu 2012, 7). It highlights the plight of black children who were denied the right to education due to their parents' ignorance and the blacks' world controlled by the racial imperialism of the whites that denied education to black children and forced them to work in the confines of the cotton fields.

Later in his life, Brownfield's knowledge of his young daughter, Daphne's work in the cotton fields enables him to find his family trapped in the chain of slavery that had begun with Grange. Daphne's mopping the cotton bushes with arsenic makes him realize the complex web of cultural dominance and slavery. The omniscient narrator observes, "It was the summer that he watched, that he had to teach, his frail five-year old daughter the tricky, dangerous and disgusting business of hand mopping the cotton bushes with arsenic to keep off boll weevils." (Walker 2004, 70) His daughter's work and her plight leaves him heartbroken and he senses that he is trapped in the same cycle of oppression and exploitation that his father lived. Realizing it, Brownfield contemplates suicide as he fails to get his family out of economic depression phase his family is witnessing. The narrator observes, "This was the year he first saw how his own life was becoming a repetition of his father's. He could not save his children from slavery..." (Walker 2004, 72) When he fails to find any way out, he starts taking out his anger on his wife, Margaret declaring her responsible for his failures. In this way, he too like Grange continues the same pattern to blame the whites and his wife for his own inactions as he fails to encounter with the cultural dominance of the whites and find any solutions to his problems. Like Grange, Brownfield too blames the white culture for his own inactions. Instead of accepting his faults and weaknesses, he blames the whites even for the results of his own actions. He believes as rightly stated by M. Evans: "that white folks are to blame for everything including his behaviour." (Evans 1983, 460)

He too like Grange, instead of confronting cultural dominance of the whites, vents his anger and frustration at his wife and three daughters. The narrator captures Brownfield's indifference and irresponsible behaviour towards his daughters in the following words:

TO HIS THREE DAUGHTERS Brownfield gave the dregs of his attention only when he was half drunk. To him they were not really human children, although his heart at times broke for them. He could not see them as innocent or even as children. He scolded Ornette, who had come a year after Daphne, with the language he would use on a whore. And the baby, Ruth, he never touched. (Walker 2004, 96)

Brownfield is torn in the cultural flux that he cannot escape the ghetto; the way Grange could break. The painstaking efforts and hardships in bigoted order emanate in him arrogance and violence that he uses as means of violence against his own family and thus it results in his family deterioration. The narrator recapitulates Brownfield's rough treatment as "He had enslaved his own family, given them weakness when they needed strength, made them powerless before any enemy that stood beyond him. Now when they thought of "the enemy," their own father would straddle their vision." (Walker, 287) Brownfield's irresponsible behaviour, his unaccountability and ignorance caused by fanaticism of the white culture, cripples down the entire family and destroys it terribly, making Brownfield alcoholic and more violent ever before. The pangs of cultural authority and superiority are so disturbing and destructive that makes the place menacing for the survival of the African Americans. In her interview with John O'Brien, Alice Walker regards The Third Life of Grange Copeland "a grave book" in which the characters observe "the world as almost entirely menacing" (Byrd, 2010, 50)

The white culture constantly made the blacks to move from one place to other. They did not permit the blacks to settle at one place and live life comfortably; rather they overworked the blacks and terminated them from the work after exploiting them for years of hardships. Mem Copeland is no exception to it. She is very much disturbed in xenophobic world that does not permit her to settle at one place. It results in disturbing her daughters' education and 
they begin to suffer. Mem's plight throws light on the cultural crisis in which the white landlords did not allow the blacks to settle at one place. Sharecropping system kept them moving from one place to the other and that chain of moving had no end in their life. The narrator rightly captures this reality in Mem to throw light on her frustration she has experienced:

Being forced to move from one sharecropper's cabin to another was something she hated. She hated the arrogance of the white men who put them out, for one reason or another, without warning or exploitation. She hated leaving a home she'd already made and fixed up with her own hands. She hated leaving her flowers, which she always planted whenever she got her hands on flower seeds. Each time she stepped into a new place, with its new, and usually bigger rat holes, she wept. Each time she had to clean cow manure out of a room to make it habitable for her children, she looked as if she had been dealt a death blow. (Walker 2004, 77-78)

Mem Copeland tolerates the extremity of cultural dominance of the whites that drives her and her children to move from one place to the other. The moment she realizes the problem of her daughters' health, education and proper care, she rebels the circumstances and fights with the manipulative and abusive forces. She supports her husband despite his arrogance and negligence. She fails to understand the complex nature of her utilization in cultural imperialism. In Racism and Feminism: The Issue of Accountability, Bell Hooks explains, "The inability of American women to understand racism in the context of American politics is not due to any inherent deficiency in woman's psyche. It merely reflects the extent of our victimization." (Hooks 1990, 119)

Mem Copeland finds the white cultural environment hostile and the places she lived menacing for their existence and survival. Whereas Brownfield finds his existence at such menacing hostile places fit to inhabit as his life is destined to the lot he is conditioned in imperialistic world. The narrator rightly observes:

For Brownfield, moving about at the whim of a white boss was just another example of the fact that his life, as it was destined, had "gone haywire," and he could do nothing about it. He jumped when the crackers said jump, and left his welfare up to them. He no longer had, as his father had maintained, even the desire to run away from them. He had no faith that any other place would be better. He fitted himself to the slot in which he found himself; for fun he poured oil into streams to kill the fish and tickled his vanity by drowning cats. (Walker 2004, 78)

Like Margaret and Mem Copeland, Ruth too witnesses intolerance, but she cannot remain passive like them. To encounter the cultural dominance and authority of the whites, she turns to the civil rights movement and takes interest in it. She encounters civil right workers distributing some pamphlets regarding the movement and dares to drop the same at the white neighbour who leaves next to them. Grange has already informed her with the white neighbour's evil motive to usurp their land. Ruth's dropping of the pamphlets at the neighbours' farm is her first action and an entry into the civil rights movement. She is fascinated towards the movement, as she too desires for the equality and keeps a constant watch on the moves of the civil rights workers around. Education denied to Brownfield brings transformation in her life and expands her scope of knowledge. In a court on the day of verdict, Grange shoots Brownfield, saves her from his exploitation, and makes her free to make her way to any continent where she would find the environment fit for her survival and growth. Ruth's story towards the end of the novel offers more hopes for greater possibilities of freedom, growth and emancipation in an equal society that she would strive for and go beyond the black and white culture that is antagonistic to each other. Bloom Harold beautifully captures this would be reality in Ruth's life as below:

While Brownfield is a terrifying example of how the South can physically enslave and spiritually cripple black people, Ruth's story offers considerable hope because she is able to leave the South, rejecting the racist world which destroys Brownfield and, in so doing, move toward a larger, freer world which offers her fresh possibilities.(Bloom 2007, 91)

To conclude, racial and cultural crisis not only destroyed the lives of black men but it also critically affected the lives of black women and children in American society. Grange and Brownfield Copeland are the terrifying representatives and victims of destructive cultural imperialism. The involvement of Ruth in the civil rights movement and the active participation of even some whites signals towards the March for the world class human society that will be based on freedom, fraternity, equality, and social justice to benefit the entire humanity residing on this beautiful plant-the Earth. 


\section{Works cited:-}

1. Byrd, Rudolph P. The World Has Changed: Conversations with Alice Walker. New York: The New Press, 2010.

2. Hooks, Bell. Racism and Feminism: The Issue of Accountability. Ain't a Woman: Black Women and Feminism. London: Pluto Press, 1990.

3. Bloom, Harold (edited). Bloom's Modern Critical Views Alice Walker New Edition Butler, United States of America: Chelsea House, 2007.

4. Christian, Barbara. Black Feminist Criticism: Perspectives on Black Women Writers. New York: Pergamon, 1985.

5. Evans, M. ed., Black Women Writers: Arguments and Interviews. London: Pluto Press, 1983.

6. Hubbard, Dolan. Society and Self in Alice Walker's In Love and Trouble. American Women Short Story Writers: A Collection of Critical Essays. Ed. Julie Brown. New York: Garland Publishing, Inc, 2000.

7. Mhandu, Edwin. Transcending the Inauspicious Curse? Black Violence and the Victim-focused Identity in Alice Walker's Works. American International Journal of Contemporary Research. Vol.2, No.10, October 2012.

8. SERAMAN, N. and A.R. THILLAIKKARASI. "Rage and Rebellion of Grange Copeland in Alice Walker's Third Life of Grange Copeland. Volume: 3, Issue: 6, June 2013.

9. Walker, Alice. The Third Life of Grange Copeland. London: Orion Books Ltd., 2004. 